\title{
Codes of Ethics Content: UK and Australian Corporations
}

\author{
Authors: G. Wood, G. Whyatt, M. Callaghan \& G. Svensson
}

\section{Introduction}

In the twentieth century, industrialized economies around the world enacted legislation to protect free trade, securities dealings, consumers, suppliers, shareholders and more recently other stakeholders (Hoffman et al., 2003; Wood and Callaghan, 2003; Svensson and Wood, 2008). This legislation was prompted by some major business organizations in the developed world seizing opportunities to profit unethically and, in many cases, illegally. Subsequently, as the powers of large corporations grew and the malfeasance of others was becoming recognized, collectively, they were confronted by greater expectations from the societies in developed nations to behave in an ethical manner (Cleek and Leonard, 1998; Sørensen, 2002; Joyner and Payne, 2002; Lea, 1999; Spiller, 2000; Wood, 1991).

When corporations realize that there is a need to examine their ethical practices and to move forward proactively in this area, they invariably seek to develop artefacts that they can institute within their organizations to signal to all stakeholders, both external and internal, that they have a commitment to business ethics (Wood, 2002; Preuss, 2010). The implementation of a code of

ethics is one such practice because it is a tangible artefact that can be seen and acted upon by all.

These codes have been found to evolve over time and to differ between different national contexts (Singh et al., 2005; Arnold et al., 2007; Whyatt, Wood and Callaghan, 2012).

\section{Definitions of Codes}

Corporations need to define and articulate the acceptable behaviours that they wish to inculcate (Singhapakdi and Vitell, 2007). Codes of ethics are a "distinct, and formal document which consists of moral standards that help guide employee or corporate behaviors" (Schwartz, 2005, p. 27). These documents vary in length, as does the breadth and extent of the topics covered.

Langlois and Schlegelmilch (1990, p. 522) define a corporate code of ethics as,

"a statement setting down corporate principles, ethics, rules of conduct, codes of practice or company philosophy concerning responsibility to employees, shareholders, consumers, the environment, or any other aspects of society external to the company."

Kaptein and Schwartz (2008, p. 113) postulate that a

"business code is a distinct and formal document containing a set of prescriptions developed by and for a company to guide present and future behavior on multiple issues of at least its managers and employees toward one another, the company, external stakeholders and/or society in general."

The common themes amongst the definitions are that they are centred upon a code being a statement that encapsulates the moral standards of behaviour that the company wants to see exhibited by its employees. Codes recognise that employee actions must be considered in light of a myriad of 
stakeholder interests both internal and external to the organization and that their actions will impact upon their society as a whole.

\section{The Benefits of Codes}

There have been mixed findings by research studies on the effectiveness of corporate codes of ethics in influencing behavior. Some studies have found that having a code of ethics does have a positive impact on the ethical behaviour of the employees of the organisation (Ferrell and Skinner, 1988; McCabe, Trevino and Butterfield, 1996; Stohs and Brannick, 1999; Adams, Tashchian and Shore, 2001; Wotruba, Chonko and Loe, 2001; Somers, 2001; Bodolica and Spraggon, 2015). Other studies have found this causal relationship not to be conclusively the case (Ford, Gray and Landrum, 1982; Cleek and Leonard, 1998; Mathews, 1998; McKendall, Demarr and Jones-Ridders, 2002). These findings are in many ways contradictory, yet they suggest that codes may be potentially valuable in corporate decision-making and as a signal to stakeholders of a company's organizational values.

Bodolica and Spraggon (2015) contend that the purpose of the code is not only to set the tone for the expected organizational conduct, but also to guide employees in the values and behaviours that a company wishes to instil into the organizational culture.

Kaptein (2014, p. 5) drawing upon his work of 1998 and 2011 put forward his belief that,

"A code of ethics first and foremost creates clarity as it describes ethical behavior and distinguishes it from unethical behavior. A code can also foster commitment through its expression of values and principles employees can identify with, feel inspired by, be proud of, and become motivated to realize. A code of ethics can also create more space to discuss ethical issues given that it offers a normative framework that facilitates discussion and identifying and reporting violations (Kaptein 1998, 2011a)."

Codes of ethics provide a framework that helps employees understand what is expected of them and therefore assists them to be able to evaluate different possible courses of action in a variety of situations (Adams et al., 2001; Singh et al., 2011; Whyatt, Wood and Callaghan, 2012). As Preuss et al. (2016) state, codes have become one of the most widespread tools used by corporations to inculcate their value systems into their cultures.

A review of the articles published in the fifty years of the life of the Journal of World Business established seven major themes across the journal in those years (Harvey and Moeller, 2016). The third theme is 'Ethics' which Harvey and Moeller (2016, p. 6), define as, "an understanding of what is considered to be "right" and "wrong" conduct". They go on to expand this theme into four areas for further investigation, two of which are: reconciling ethical standards among developed, transitional and emerging economies; and the integration of global employees in global organizations. The way that a corporation can look to achieve these lofty goals is to use a code of ethics as an instrument to operationalize said goals. A code should outline, from the perspective of the organization, what is 'right' and 'wrong' behavior. In multinationals the code of ethics is the foundation stone upon which organizations endeavor to ensure that all employees, from all functional areas and geographic regions of the organization, can be integrated equally into the ethos of the organization.

Page 2 of 17 


\section{Comparison Studies}

Langlois and Schlegelmilch (1990) found differences between European and American codes in that while most ethical issues transcend national barriers, there were differences in the issues addressed by American and European (British, French and West German) codes. In particular, they concluded that European companies emphasized employee responsiveness to company activities, while firms in the United States stressed company responsiveness to employee requirements of fairness and equity. Furthermore, the study found differences among the codes of British, French and German companies.

Studies of codes of ethics and ethical values across cultures, have found that ethical beliefs vary across cultures and the emphasis on certain aspects of the content of a code of ethics may also differ between cultures (Arnold et al., 2007).

It is therefore critical, as emphasised by Singh et al. (2011) and re-emphasised by Bodolica and Spraggon (2015), that researchers monitor the content of codes of ethics to take account of these regional differences and changes over time (see Figure 1). This study aims to understand the differences in the content of codes of ethics between two cultures at a point in time, and in so doing the objectives are twofold:

1. To establish the current topics (TIME) included in today's codes of ethics in the largest corporations operating in the United Kingdom and Australia.

2. To examine if there are distinct differences (CULTURE) in the contents of the codes of ethics of the top 50 companies listed on the London Stock Exchange, as compared to the contents of the codes of ethics of the top 50 companies listed on the Australian Stock Exchange.

Insert Figure 1

The study of code content across cultures is therefore not an esoteric exercise, but one that can provide tangible evidence of what large corporations operating across many business jurisdictions are trying to achieve in their desire to be seen by their stakeholders as practising Corporate Social Responsibility.

\section{Comparative Indicators - Australia and the United Kingdom}

The economies of both countries are well developed. Australia has a prosperous Western-style capitalist economy, with a per capita GDP on par with the four dominant West European economies. Up until 2014, Australia had continuous economic growth for the previous 20 years based ostensibly on the resource boom in Asia and in particular on the insatiable desire for raw materials in the Peoples Republic of China. The Global Financial Crisis had a limited effect on Australia due to the strength of its banking sector. It needs to be noted that in 2015, the Australian economy was not as robust as in 
the previous two decades, due largely to a fall in commodity prices that have impacted upon its GDP (CIA, 2015).

After Germany and France, the United Kingdom is the third largest economy in Europe. The services sector is the key driver of its economy. Unlike Australia, it did not fare well during the Global Financial Crisis and when the Cameron Government came to power in 2010 it implemented an austerity program in an endeavor to return the country to a better fiscal position (CIA, 2015).

The United Kingdom's GDP is US\$2,435 million (\$US Purchasing Power Parity), Australia's is US $\$ 1,100$ million (see Table 1). In both countries, the services sector generates the majority of the GDP. There is a discernible difference in the GDP per capita for each country with Australia having a $17.6 \%$ greater GDP per capita (Australia: US\$54,800; UK: US\$46,600).

In 2014, the inflation rate in both countries was below $3 \%$ (see Table 1) with the UK at $2 \%$ and Australia at 2.7\%. The UK in 2014 had a greater GDP Real Growth rate of $3.2 \%$ as compared to Australia's of $2.8 \%$. The UK economy had an inflation rate of $1.6 \%$ as compared to Australia of $2.7 \%$. When one examines the Public Debt to GDP ratio, the Australian economy is in a much sounder position than the UK economy. Australia's ratio is at $34 \%$ of GDP whilst the UK's ratio is at $86.6 \%$ of GDP. Life expectancy in Australia is 82.07 years whilst in the UK it is 80.42 years. The population growth rate in Australia of $1.09 \%$ is twice that of the UK at $0.54 \%$, however, on a world scale, both economies are similar in many respects.

Insert Table 1

Australia and the United Kingdom were among the countries studied by Hofstede in developing his dimensions of national culture. In that seminal study, he identified the following four dimensions of national culture: Individualism versus Collectivism (IC); Large or Small Power Distance (PD); Strong or Weak Uncertainty Avoidance (UA); Masculinity versus Femininity (MF) (Hofstede, 1983). Hofstede's research, involving a data bank of 40 countries and 116,000 questionnaires, allowed him to assign an index value (between 0 and about 100) on each of the four dimensions. Scores on these dimensions for Australia and the UK are shown in Table 2.

Insert Table 2

On Individualism versus Collectivism, a measure of the relationship between an individual and his fellow individuals, Australia is (90) and the United Kingdom is (89). These scores are two of the three highest, only being higher in the USA (91) (Hofstede, 2017). Both cultures are highly individualistic with an expectation that one looks after oneself and one's family.

On Power Distance, a measure of the unequal distribution of power in society, the Australian (36), and United Kingdom (35) scores are close in value. Both societies appear to tend towards egalitarianism with one's worth decided by one's actions from birth rather than one's entitlement at birth. Both cultures have a tendency towards fair play (Hofstede, 2017).

The Uncertainty Avoidance Index (UAI), which is a measure of how a society deals with uncertainty, is related to the propensity of a culture to establish laws and formal rules, such as codes of ethics. Societies strong on Uncertainty Avoidance are more likely to establish formal rules to deal with unpredictability. Australia and the United Kingdom have scores of 51 and 35 respectively (Hofstede, 2017). 
The UK has a lower score than Australia on this dimension and a score that is comparatively low on the world scale. The British appear to be able to handle ambiguous situations more readily than do Australians.

Masculinity versus Femininity is a measure of the division of roles between the genders (Hofstede, 1983, p. 85). Both Australia [61] and the United Kingdom [66] are high on being masculine societies (Hofstede, 2017). Masculine societies are deemed to be highly success oriented and predicated on a belief that the spoils attributed to a 'winner takes all' mindset is acceptable.

Whilst one could not claim that the cultures mirror each other, one could only but be interested in the similarities that exist between them. These similarities are rooted in over two hundred years of kindred history in which Australia was a British colony from 1788 until 1901. The links between the two countries forged so long ago, are enshrined in the fact that Australia, like the United Kingdom, is a constitutional monarchy with the Head of State of both countries being Queen Elizabeth the Second of Great Britain.

\section{Method of Collection of the Codes}

The sample size of fifty was chosen based upon the work of Winkler (2011) who surveyed the top thirty companies listed on the DAX Top 30. Winkler's reasoning for using the top thirty companies in Germany is applicable in the context of this study in Australia and the United Kingdom. He contended that these blue chip, top thirty companies listed on the Frankfurt Stock Exchange were, "arguably the most visible German enterprises and therefore the most important as perceived by investors, business analysts and the public." Winkler (2011, p. 657). Winkler (2011) believed that an analysis of the codes of these companies was appropriate, because they were leaders in the German economy and could therefore be seen as representative of large German companies.

The method of collection was to obtain the list of the 50 top companies listed on the London Stock Exchange [LSE,] and the 50 top companies listed on the Australian Stock Exchange [ASX] based on market capitalisation. The code of each of these companies was then sourced from the internet. Of the LSE listed top 50 companies (LSE, 2015), 46 codes were able to be downloaded from the internet, whilst in Australia it was the codes of 47 companies that were able to be downloaded from the internet (ASX, 2015). The remaining companies in each jurisdiction all mentioned a code of ethics on their websites, but it was not possible to gain access to them.

Two companies, BHP Billiton and Rio Tinto, were listed on both stock exchanges.

\section{Presentation of Results}

Of those companies listed on the Australian Stock Exchange, 85.1\% are Australian based whilst only $54.3 \%$ of companies listed on the United Kingdom Stock Exchange are UK based. The list of the UK Stock Exchange top 50 companies is more international in make-up than the Australian Stock Exchange top 50 listed companies [Table 3].

Insert Table 3 


\section{Content Analysis of the Codes of Ethics: Proffering a New Instrument of Analysis}

This study of the content of codes of ethics in both jurisdictions builds upon the work of Cressey and Moore (1983); Mathews (1987); Lefebvre and Singh (1992); Wood (2000); Singh, et al. (2005); Singh (2006); Svensson et al. (2009); Singh et al. (2011) and Singh (2015), in which the contents of codes of ethics across the corporate sectors of the USA, Australia, Canada and Sweden were analysed to assess what items were incorporated into the codes.

Wood (2000) used eight dimensions with 62 items and performed the content analyses differently from Lefebvre and Singh (1992) and Mathews (1987). In Wood's (2000) case, the frequency of mention was maintained within each item, but the amount of space or 'implied relative importance' of each item was not used. The main reason proffered for this modification to the methodology was that the amount of space devoted to an item within the code may not necessarily correlate with the importance that the organization attaches to it. The space devoted to it could well be a feature of the difficulty in expressing the item, rather than being implied as to its degree of worth. Some of the most central tenets in a culture can be expressed easily because we understand the importance of the item itself and it is integral to our culture. Wood's approach has been used by Preuss (2010) in his work on UK codes and on codes being used in the developing world by major corporations (Preuss et al., 2016). The study by Singh et al. (2005) appears to be the last study conducted in Australia, and the work of Preuss (2010) is the most recent study undertaken in the UK on code content.

The content analyses of this research, uses the approach applied by Wood (2000). Since Wood's study not only has there been a proliferation in the themes that are prominent in codes of ethics, but also the code items have become more specific. The list has grown to 86 items across seven dimensions as shown in Figure 2.

Insert Figure 2

This finding is interesting in light of the work of McDonald (2009) who observed that over time codes have moved from a narrow focus on issues such as conflict of interest to now encompass issues that focus more so upon stakeholders and society at large. Also, Singh's (2015, p. 382) work contends that the codes of ethics of Canada's largest corporations "have become more prescriptive and suggests a desire to avoid uncertainty in addressing possible ethical dilemmas..."

In the area of 'Conduct on Behalf of the Company' [Table 4], the 14 items were increased to 18 items. Previously, items 2 and 3 had been combined, but it was decided that as the item was double barrelled, then it was desirable to split it into two separate items (Svensson, 2018). Stakeholders were often mentioned in recent codes, so they became item 6 and to catch any other conduct not listed then an 'Other Conduct on behalf of the Company' category was included as item 18.

The greatest growth of categories was in the area of 'Conduct against the Company' [Table 5]. Originally there were 8 items, being item numbers 19-22 and 34-37 in the current document, but after reading the codes it became apparent that other items were being mentioned frequently and needed to be recorded as individual items to give greater clarity to code content. These extra 11 items are in many ways reflective of the evolution of our current culture during the Internet Age, such as the 'Use of computer software and or hardware'; 'Intellectual property rights'; 'Communicating with the media

Page 6 of 17 
and outside publics' which also had links to the use of social media; 'Truth in communication including advertising'. A number of the other items are indicative of a greater expectation of greater respect for each other in our dealings today rather than thirty years ago. Issues such as 'Relations with fellow employees'; 'Employee harassment and discrimination'; 'Retaliation against others'; and 'Post-employment obligations' highlight this shift in attitudes in respect to acceptable behaviour against the company and each other.

In respect to 'Laws and Conventions cited' [Table 6] 7 items have been added. The inclusions of 'Copyright'; 'Data Protection'; 'EEO'; 'Money Laundering'; and 'Labour' highlight a shift in attitude by legislators to these practices and the need to ensure the integrity of these processes. The copyright and data protection laws are directly related to the increase in the capabilities of the internet to aid individuals who do not want to exhibit the correct behaviours. The acknowledgment of the need to consider 'Human Rights' and the 'UN Global Compact' signifies a shift in focus of many companies to consider these issues in their everyday dealings in the marketplace. This change in behaviour is reinforced in Table 7 'Government Agencies and Conventions' where the 'United Nations'; 'Organization for Economic Co-operation and Development'; and the 'International Labour Organization' are now being named in codes of ethics.

In respect to the 'Types of Compliance and Enforcement' [Table 8] only one extra item was added and that was Item 72. That item, in respect to seeking advice from, or reporting breaches to, an organizational representative, has had added to it: that an employee is now also advised to contact people in the 'Human Resource Management Department'. In previous readings of the codes, the reporting of issues of concern was directed towards those individuals and/or entities that are more compliance related such as senior managers, supervisors, legal representatives, watchdog committees and /or signing compliance affidavits to affirm that one has abided by the intent of the code. The inclusion of the Human Resource Management Department may highlight a shift in significance as to the role of HRM professionals within the organization. In Table 9 'Penalties for Illegal Behaviour' and in Table 10 'General Information' there were no extra items included.

\section{Conduct on Behalf of the Company}

Conduct on Behalf of the Company [Table 4] examines those activities that can occur in the marketplace in the name of the company. The code items that show a significance difference at greater than $\alpha=0.05$ are Relations with 'Customers', 'Suppliers', 'Employees', 'Stakeholders', 'Investors'; 'Payments or political contributions to governments or government officials and employees' and the 'Accepting and or giving of bribes or kickbacks gifts and entertainment'. These findings are not surprising as one would hope and expect that organizations in both jurisdictions are focused upon their customers, their suppliers, their employees, their investors and their impacts upon stakeholders. In both jurisdictions there are laws that govern not only these interactions, but those behaviours that may be perceived as bribes or kickbacks or anything outside of the law seeking to obtain a competitive and/or financial advantage that is deemed unacceptable and in many cases illegal.

Those elements of the code that are cited at a significance difference of equal to or less than $\alpha=0.05$ are: 'Relations with home government'; 'Relations with competitors'; 'Relations with foreign governments'; 'Civic and Community affairs'; 'Relations with consumers'; 'Environmental affairs'; 'Product safety and product quality'. The United Kingdom codes are more engaged with each one of

Page 7 of 17 
these items. As the United Kingdom codes represent some of the larger multinationals in the world, it is not surprising that there would be a greater focus on relations with both one's home government and foreign governments. The striking differences between the two groups of codes, in the areas of 'Civic and Community affairs'; 'Environmental affairs' and 'Product safety and product quality', are of real interest. In both jurisdictions in the last twenty years there has been an increased expectation for businesses to be involved with their community and to strongly exhibit a responsibility to society at large. It is assumed that this requires a parallel focus upon environmental affairs and the need to produce safe products of high quality.

Insert Table 4

The question as to 'Why are UK listed companies so far ahead of Australian listed companies in these areas?' is not easily answered. The difference may be explained by the fact that the codes of UK based organizations represent countries across a wider spectrum of the world's business regions than is the case with Australian organizations. Some of these practices in developing countries are not as well enshrined as they are in the developed world in which Australian organizations predominantly do business.

Point 18 'Other conduct on behalf of the company' produced many and varied responses from both groups. The array of points in the Australian codes is less colourful than those in the United Kingdom codes.

In Australia, some of the points deemed as more interesting were: one must tell the truth to regulators; no employee can give gifts of drugs to a third party; market manipulation is not to be accepted; when speaking at conferences one must ensure that commercial-in-confidence propriety is maintained; no computer hacking of competitors is to be undertaken; and if there is a conflict between the laws in the jurisdiction where one is working and the ethos of the code, then one must adhere to the higher standard of behaviour.

In respect to point 18 , in the United Kingdom based codes, the array of points were: there is to be no distorting of markets; one shall not do business with terrorists; nor work with organised crime; an employee should not engage lobbyists; nor should an employee engage in industrial espionage; and if there is a conflict between the laws in the jurisdiction where one is working and the ethos of the code, then one must adhere to the higher standard of behaviour.

In point 18, the topic of Facilitation Payments arose across both groups of codes. Facilitation payments are those payments made to facilitate business that is seen by many as a sanitized term for giving a bribe or a kickback (Argandoña, 2005).

The general consensus in Australia was that one should not indulge in facilitation payments at all, but not all organizations, as one company stated, subscribed to this view. As facilitation payments are illegal under the 2010 UK Bribery Act, one would expect it to not be supported by any company in the UK, but one company said it was acceptable if an employee's safety was at risk.

Conduct Against the Company:

Page 8 of 17 
The area of 'Conduct Against the Company' [Table 5] examines those activities that can occur in the marketplace against the best interests of the company as done by its own employees. The code items that show significant difference at equal to or less than $\alpha=0.05$ are 'Integrity of books and records'; 'Intellectual property rights'; 'Drugs including alcohol'; 'Participation in the political process'; 'Retaliation against others'; 'Truth in communication including advertising'. The only one of these items that occurs more in Australian codes than in UK codes is 'Drugs including alcohol'. UK companies do business across a greater diversity of countries than most Australian listed companies do. This could lead to greater awareness in the UK of the possibility that issues more accepted as being de rigeur in terms of consideration in the Australian context, may be flouted in some of the overseas jurisdictions in which they operate.

Insert Table 5

In Australia, 'Other conduct against the company' included, but was not limited to, attending an inappropriate adult venue; destroying documents if knowing of an impending investigation; misuse of employee benefits; misleading statements to auditors; introducing a computer virus; and failing to notify of a personal romantic relationship in a direct reporting relationship.

'Other conduct against the company' in the UK included, but was not limited to, not to get involved in casinos or gambling; bringing of weapons to work; tax avoidance; placing in circulation counterfeit bank notes; being exploited by criminals; obstructing investigators; not following standing instructions if there is a dawn raid by the competition authority; retaliation against those who join a union.

The differences in the two groups of responses one could suggest again is indicative of the more international marketplaces in which the UK companies engage and of practices in some jurisdictions around the world that are not usually experienced as such in Australia. Both lists have obviously been predicated upon previous or perhaps expected behaviours which in some cases are extraordinary and not expected in a workplace. The UK list is more colourful than the Australian list where bringing weapons to work; placing in circulation counterfeit bank notes and making plans for dawn raids by the competition authority seem at the extreme end of what may happen in Australian listed companies and for that matter in UK listed organizations.

\section{Laws and Conventions Cited}

The elements of the code that were cited at a difference of $\alpha=0.05$ in 'Laws and Conventions cited' are: 'Competition'; 'Environment'; 'Food and Drugs'; 'Product safety and quality'; 'Bribes or payments to government officials'; 'Copyright'; 'Boycott'; 'Money laundering'; 'Labour'; 'Human Rights'; and 'Other laws and conventions' [Table 6]. In every case, the UK frequency of mention of these elements in their codes leads their Australian counterparts. These significant differences may be due to the fact that the companies listed on the UK Stock Exchange are more global in nature than their Australian counterparts and they thus work in a variety of jurisdictions in which, as a company based in the developed world, one needs to be aware of the situations that one may encounter in less developed jurisdictions. Working in more diverse international environments leads to the UK organizations needing to ensure that their employees are cognizant of issues that centre around labour laws and human rights conventions, whilst at the same time being aware that their practices do not 
violate international conventions and laws in respect to either knowingly or unwittingly assisting malfeasance by others in their areas of business.

Insert Table 6

'Other laws/conventions' mentioned in the UK codes were the Equator principles; unions; terrorism; procurement laws; no contact with crime syndicates or drug dealers; the EU Transparency Register; corruption; freedom of association; collective bargaining.

'Other laws/conventions' mentioned in Australia were the OECD Guidelines for Multinational Enterprises; freedom of association; obeying road rules when in charge of a company vehicle. These laws/conventions mentioned in Australia were not as focussed on major structural wrongdoing, as those mentioned in the UK codes appear to be.

\section{Government Agencies and Conventions}

The two elements of the code that were cited at a difference of $\alpha=0.05$ in the area of 'Government Agencies and Conventions' are the 'United Nations' and the 'International Labour Organization' [Table 7]. As stated in respect to 'Laws and Conventions cited' [Table 6] the same reasons for greater involvement by UK listed companies in international business may well explain these differences.

Insert Table 7

\section{Types of Compliance/Enforcement}

The elements of the code that were cited at a difference of $\alpha=0.05$ in 'Types of Compliance/Enforcement' were 'Supervisor surveillance'; 'Other oversight procedures'; 'Senior role models'; and 'Other external' [Table 8]. In respect to 'Supervisor surveillance', it would appear that nearly $60 \%$ of UK companies expect supervisors to ensure that all is well with their employees, whilst in Australia this need is only formally recognised in fewer than $25 \%$ of organizations. In the UK, $45.7 \%$ of companies expect senior staff to be role models whilst in Australia this role is expected in only $25.5 \%$ of companies. There may be a link here in respect to the more proactive and engaged role that UK companies expect their supervisors to take, not only in the surveillance of others, but in scoping and modelling the correct behaviours expected of staff.

In both groups, employees needing to self-report hovers around $90 \%$ which in both groups is far in excess of the next most mentioned item. Whilst companies in both groups employ a range of types of compliance and enforcement, they expect their employees to self-monitor and self-report when they witness actions that are contrary to the best interests of their organizations, their fellow employees and/or themselves.

\section{Page 10 of 17}




\section{Penalties for Illegal Behaviour}

The only element of the code that was cited at a difference of $\alpha=0.05$ in 'Penalties for Illegal Behaviour' was 'Dismissal/Firing' [Aus:85.1\%:UK:54.3\%] [Table 9]. One should not jump to the conclusion that UK companies in only just over $50 \%$ of companies consider this option, because whilst not explicitly stated as such, in UK companies, one would expect, that miscreant behaviours would invoke dismissal and firing, but this item may well have been subsumed into the element of 'Other internal penalty'.

Insert Table 9

\section{General Information}

The only element of the 'General Information' [Table 10] that is cited at a difference of $\alpha=0.05$ or less is 'Letter/Introductory remarks from the CEO' [Aus:55.3\%:UK:89.1\%]. When the basis of this classification instrument was constructed over thirty years ago by Cressey and Moore, (1983) the internet had not been invented and code documents had to be all encompassing in what was presented to employees by the company. A forward commentary supporting the code from the CEO or another significant officer in the company conferred the imprimatur of the senior management on the document for employees as to the need to know of and abide by the code. Since the invention of the internet and its now pervasive nature, over the last twenty years, in all that we do, a code now may be one of many documents that is considered required by organizations and is often loaded upon the company website in an area focussed on CSR, with a general forward from the senior manager expressing an employee's need to engage with the code that may not be specifically included in the code itself.

Insert Table 10

\section{Managerial Relevance}

In the last thirty years, many major corporations have become notorious for their failure to uphold both legal and ethical standards. It is of no surprise that business ethics continue to be a key concern to the public, regulators and governments. As a result of these issues most major corporations have adopted a code of ethics, however, to influence employee behavior at all levels, their challenge today is ensuring that such codes are embedded in their business culture. Existing research has shown that within an international arena, codes of ethics take on additional importance and complexity. To be effective, the articulation of these statements of ethical behavior standards must recognize both the national culture in which the corporation is based, and the national cultures in which the organization 
operates, therefore it is crucial that management understand both: i) differences in national cultures, and ii) the influence that these cultures have on ethical standards and employee behavioral responses to them.

This research contributes to this understanding by demonstrating the differences and similarities in expected ethical standards in organizations based in two countries that, on the face of it have a shared cultural history. This research finds that although there are many similarities, there are some major differences between UK and Australian approaches. The authors speculate that these differences may be due to cultures based on different life styles, and that also Australian companies have moved into international marketplaces more recently than those in the UK, however, no causal path is identified.

\section{Conclusion:}

The establishment and use of codes of ethics by corporations have become mainstream across the developed world (Erwin, 2011) and, as previously noted, numerous studies have been conducted over the last thirty years in respect to codes of ethics. Studies that have undertaken cross cultural comparisons of codes of ethics have indicated that national differences in ethical beliefs and values are reflected in the content of codes employed by the corporations that operate within those countries (Arnold et al., 2007). The importance of investigating and noting such differences is essential to understanding and evaluating ethical behaviour in the workplace (Singh, 2011; Bodolica and Spraggon, 2015).

It is apparent from the reading of the codes in this study that the contentions of McDonald (2009) and Singh (2015) that codes are becoming more prescriptive in their content is correct with an increase from 62 code items in previous studies to 86 code items uncovered in this study. Organizations are becoming ever more prescriptive in their delineation of behaviours that are either acceptable and/or unacceptable in business practices today. The array of items mentioned in the 'Other Items' areas is an interesting insight into some of the behaviours that organizations have either witnessed and/or from which they have suffered. Such items as, no computer hacking of competitors is to be undertaken; one shall not do business with terrorists; nor work with organised crime; destroy documents if knowing of an impending investigation; place in circulation counterfeit bank notes; and being aware of and following standing instructions if there is a dawn raid by the competition authority, make one think deeply about what our organizations are seeing, experiencing and/or trying to combat in their various marketplaces.

Based on cultural heritage and legal commonality, it would be reasonable to assume that few substantive differences would be evident between the approaches of Australian and UK codes of ethics. The expectation that parity would exist between respective codes of ethics is reasonable. At face value, this appears to be supported in this research with 51 of the 86 items (59.3\%) showing no significant difference at $\alpha=0.05$, however significant differences $(\alpha=0.05)$ between the UK and Australian codes were found across the remaining 35 of the 86 items, with Australian codes exceeding the UK on the frequency of only one item, within the 'Penalties for Illegal Behaviour': 'Drugs including alcohol' (59.6\% included this item, compared to $32.6 \%$ in the UK). The Australian culture of a more recreationally based lifestyle may well be a key influencer in the need for Australian corporations to be more prescriptive on this item.

This research provides valuable insights into the similarities and differences that exist between the expected ethical standards in corporations based in two close and culturally related business

\section{Page 12 of 17}


jurisdictions. Highlighting these insights is valuable for both scholars and practitioners, and establishes a very real contribution to knowledge. Whilst these results should only be considered as a reflection of the sample under investigation, this paper does provide a sound basis for further investigation and cross country comparisons of corporate codes of ethics across both differing and/or similar cultures and provides a more contemporary instrument for analysing codes than heen previously available. This paper is a valuable contribution to contemporary research practice in this area, as it: i) creates a series of potential benchmarks that can be compared over time, ii) substantially enhances our knowledge of the development of code content over time, and iii) provides insight into the impact of culture where differences occur. 


\section{References}

Adams, J., Tashchian, A. and Shore, T. (2001), "Codes of ethics as signals for ethical behavior", Journal of Business Ethics, Vol.29 No. 13, pp. 199-211.

Argandoña, A. (2005), "Corruption and Companies: The Use of Facilitating Payments", Journal of Business Ethics, Vol. 60 No. 3, pp. 251-264.

Arnold, D. F., Bernardi, R. A., Neidermeyer P.E. and Schmee, J. (2007), "The Effect of Country and Culture on Perceptions of Appropriate Ethical Actions Prescribed by Codes of Conduct: A Western European Perspective among Accountants", Journal of Business Ethics, Vol. 70 No. 4, pp. 327-340.

Australian Stock Exchange, (2014), “Top 50 Companies by Market Capitalisation”, available at: http://www.marketindex.com.au/asx50 (accessed January 17, 2015).

Bodolica, V. and Spraggon, M. (2015), “An Examination into the Disclosure, Structure, and Contents of Ethical Codes in Publicly Listed Acquiring Firms", Journal of Business Ethics, Vol. 126 No. 3, pp. 459-472.

CIA (2015), “The World Fact Book”, Washington, DC: CIA. http://www.cia.gov, (accessed June 10, 2015).

Cleek, M.A. and. Leonard, S.L (1998), “Can corporate codes of ethics influence behaviour?”, Journal of Business Ethics, Vol. 17 No. 6, pp. 619-630.

Cressey, D. R. and Moore, C. A. (1983), "Managerial values and corporate codes of ethics", California Management Review, Vol. 25 No. 4, pp. 53-77.

Erwin, P.M (2011), "Corporate Codes of Conduct: The Effects of Code Content and Quality on Ethical Performance”, Journal of Business Ethics, Vol. 99 No. 4, pp. 535-548.

Ferrell, O. C. and Skinner, S. J. (1988), "Ethical behaviour and bureaucratic structure in marketing research organizations", Journal of Marketing Research, Vol. 25 No. 1, pp. 103-109.

Ford, R., Gray, B. and Landrum, R. (1982); "Do organizational codes of conduct really affect employees' behaviour?”, Management Review, Vol. 72, pp. 53-54.

Harvey, M. and Moller M, (2016), "A brief commentary on the past, present and future trajectory of the Journal of World Business", Journal of World Business, Vol. 51 No. 1, pp. 6-9.

Hoffman, K. D., M. Czinkota, P. Dickson, P. Dunne P, A. Griffin, M. Hutt, B. Krishnan, J. Lindgren, R. Lusch, I. Ronkainen, B. Rosenbloom, J. Seth, T. Shimp, J. Sigauw, P. Simpson, T. Speh and J. Urbany (2003); Marketing Best Practice,. $2^{\text {nd }}$ edition, Thomson, Ohio.

Hofstede, G. (1983), "The cultural relativity of organizational practices and theories", Journal of International Business Studies, Vol. 14 No. 2, pp. 75-89.

Hofstede, G. (2017), "Hofstede Insights: Compare Countries", available at: https://www.hofstedeinsights.com/product/compare-countries/ (accessed December 27th, 2017).

\section{Page 14 of 17}


Joyner, B. E. and Payne, D. (2002), "Evolution and Implementation: A Study of Values, Business Ethics and Corporate Social Responsibility", Journal of Business Ethics, Vol. 41 No. 4, pp. 297-311.

Kaptein, M. (2015), “The Effectiveness of Ethics Programs: The Role of Scope, Composition, and Sequence”, Journal of Business Ethics, Vol. 132 No. 2, pp. 415-431.

Kaptein, M. and Schwartz, M. (2008), "The Effectiveness of Business Codes: A Critical Examination of Existing Studies and the Development of an Integrated Research Model", Journal of Business Ethics, Vol. 77 No. 2, pp. 111-127.

Langlois, C. C. and Schlegelmilch, B. B. (1990), "Do corporate codes of ethics reflect national character? Evidence from Europe and the United States", Journal of International Business Studies, Vol. 21 No. 4, pp. 519-539.

Lea, D. (1999), "Corporate and public responsibility, stakeholder theory and the developing world", Business Ethics: A European Review, Vol. 8 No. 3, pp. 151-162.

Lefebvre, M. and Singh, J.B. (1992), "The Content and Focus of Canadian Corporate Codes of Ethics", Journal of Business Ethics, Vol. 11 No. 10, pp. 799-808.

London Stock Exchange, (2014), "All Companies on the London Stock Exchange at 31 Dec 2014", available at: http://www.londonstockexchange.com/home/homepage.htm (accessed January 17, 2015).

Mathews, M.C. (1987), "Codes of Ethics: Organizational behavior and misbehavior", Research in Corporate Social Performance and Policy, Vol. 9, pp. 107-130.

Mathews, M. C. (1998), Strategic Intervention in Organizations: Resolving Ethical Dilemmas, Sage, Newbury Park.

McCabe, D.L., Trevino, L. and Butterfield, K. (1996), "The influence of collegiate and corporate codes of conduct on ethics-related behaviour in the workplace", Business Ethics Quarterly, Vol. 6 No. 4, pp. 461-476.

McDonald, G. (2009), “An anthology of codes of ethics”, European Business Review, Vol. 21 No. 4, pp. 344-372.

McKendall, M., DeMarr, B. and Jones-Rikkers, C. (2002), "Ethical compliance programs and corporate illegality: Testing the assumptions of the corporate sentencing guidelines", Journal of Business Ethics, Vol. 37 No. 4, pp. 367-383.

Preuss, L. (2010), "Codes of Conduct in Organisational Context: From Cascade to Lattice-Work of Codes”, Journal of Business Ethics, Vol. 94 No. 4, pp. 471-487.

Preuss, L., Barkemeyer, R. and Glavas, A. (2016), "Corporate Social Responsibility in Developing Country Multinationals: Identifying Company and Country-Level Influences" Business Ethics Quarterly, Available on CJO 2016 doi: 10.1017/beq.2016.42.

Schwartz, M.S. (2005), "Universal moral values for corporate codes of ethics", Journal of Business Ethics, Vol. 59 No. 1-2, pp. 27-44.

\section{Page 15 of 17}


Singh, J. (2006), "A Comparison of the Contents of the Codes of Ethics of Canada's Largest Corporations in 1992 and 2003", Journal of Business Ethics, Vol. 64 No. 1, pp. 17-29.

Singh, J. (2015), "Changes in the contents of corporate codes of ethics: an institutional interpretation", European Business Review, Vol. 27 No. 4, pp. 369-388.

Singh, J., Carasco, E., Svensson, G., Wood, G. and Callaghan, M. (2005), “A comparative study of the contents of corporate codes of ethics in Australia, Canada and Sweden", Journal of World Business, Vol. 40 No. 1, pp. 91-109.

Singh, J., Svensson, G. Wood, G. and Callaghan, M. (2011), “A longitudinal and cross-cultural study of the contents of codes of ethics of Australian, Canadian and Swedish corporations", Business Ethics: A European Review, Vol. 20 No. 1, pp. 103-119.

Singhapakdi, A. and Vitell, S. J. (2007), "Institutionalization of ethics and its consequences: a survey of marketing professionals", Journal of the Academy of Marketing Science, Vol. 35 No. 2, pp. 284294.

Somers, M.J. (2001), "Ethical Codes of Conduct and Organizational Context: A Study of the Relationship Between Codes of Conduct, Employee Behavior and Organizational Values", Journal of Business Ethics, Vol. 30 No. 2, pp. 185-195.

Sørensen, A. (2002), "Value, Business and Globalisation-Sketching a Critical Conceptual Framework", Journal of Business Ethics, Vol. 39 No. 1-2, pp. 161-167.

Spiller, R. (2000), "Ethical Business and Investment: A Model for Business and Society", Journal of Business Ethics, Vol. 27 No. 1-2, pp. 149-160.

Stohs, J.H. and Brannick, T. (1999), "Codes of conduct: Predictors of Irish managers' ethical reasoning”, Journal of Business Ethics, Vol. 22 No. 4, pp. 311-326.

Svensson, G. (2018), "A toolkit to examine multi-item measures - avoiding pitfalls and flaws", European Business Review, Vol. 30 No. 1, pp. 82-92.

Svensson, G. and Wood, G. (2008), “A Model of Business Ethics”, Journal of Business Ethics, Vol. 77 No. 3, pp. 303-322.

Svensson, G., Wood, G. Singh, J. and Callaghan, M. (2009), "Implementation, communication and benefits of corporate codes of ethics: an international and longitudinal approach for Australia, Canada and Sweden", Business Ethics: A European Review, Vol. 18 No. 4, pp. 389-407.

Whyatt, G., Wood G. and Callaghan, M. (2012), "Commitment to business ethics in UK organizations”, European Business Review, Vol. 24 No. 4, pp. 331-350.

Winkler, I. (2011), "The representation of social actors in corporate codes of ethics. How code language positions internal actors", Journal of Business Ethics, Vol. 101 No. 4, pp. 653-665.

Wood, D.J. 1991, "Corporate Social Performance Revisited”, Academy of Management Review, Vol. 18 No. 4, pp. 691-718. 
Wood, G. (2000), "A Cross Cultural comparison of the Contents of Codes of Ethics: USA, Canada and Australia", Journal of Business Ethics, Vol. 25 No. 4, pp. 287-298.

Wood, G. (2002), “A Partnership Model of Corporate Ethics”. Journal of Business Ethics, Vol. 40, No. 1, pp. 61-73.

Wood, G. and Callaghan, M. (2003), "Communicating the Ethos of Codes of Ethics in Corporate Australia: 1995-2001: Whose Rights, Whose Responsibilities?”, Employee Responsibilities and Rights Journal, Vol. 15 No. 4, pp. 209-221.

Wotruba, T., Chonko, L. and Loe, T. (2001), "The impact of ethics code familiarity on manager behaviour", Journal of Business Ethics, Vol. 33 No. 1, pp. 59-69. 
Table 1: Australia and the United Kingdom: Comparative Economic and Population Statistics

\begin{tabular}{|c|c|c|c|}
\hline $\begin{array}{l}\text { Socio-Economic } \\
\text { Indicator }\end{array}$ & Australia & United Kingdom & USA \\
\hline $\begin{array}{c}\text { Gross Domestic } \\
\text { Product (Purchasing } \\
\text { Power Parity US\$) }\end{array}$ & $\begin{array}{c}\text { \$1,100 billion } \\
\text { (2014 est.) }\end{array}$ & $\begin{array}{c}\text { \$2,435 billion } \\
\text { (2014 est.) }\end{array}$ & $\begin{array}{c}\text { \$17,420 billion } \\
\text { (2014 est.) }\end{array}$ \\
\hline GDP Real Growth Rate & $\begin{array}{c}2.8 \% \\
\text { (2014 est.) }\end{array}$ & $\begin{array}{c}3.2 \% \\
\text { (2014 est.) }\end{array}$ & $\begin{array}{c}2.4 \% \\
\text { (2014 est.) }\end{array}$ \\
\hline $\begin{array}{c}\text { GDP/Capita } \\
\text { (Purchasing Power } \\
\text { Parity-US\$) }\end{array}$ & $\begin{array}{c}\$ 46,600 \\
(2014 \text { est.) }\end{array}$ & $\begin{array}{l}\$ 37,700 \\
(2014 \text { est.) }\end{array}$ & $\begin{array}{c}\$ 54,800 \\
(2014 \text { est.) }\end{array}$ \\
\hline Public Debt/GDP & $\begin{array}{c}34.5 \% \\
\text { (2014 est.) }\end{array}$ & $\begin{array}{c}86.6 \% \\
\text { (2014 est.) }\end{array}$ & $\begin{array}{c}71.2 \% \\
\text { (2014 est.) }\end{array}$ \\
\hline Inflation Rate & $\begin{array}{c}2.7 \% \\
\text { (2014 est.) }\end{array}$ & $\begin{array}{c}1.6 \% \\
\text { (2014 est.) }\end{array}$ & $\begin{array}{c}2.0 \% \\
\text { (2014 est.) }\end{array}$ \\
\hline Population & $\begin{array}{c}22,507,617 \\
\text { (July } 2014 \text { est.) }\end{array}$ & $\begin{array}{c}\text { 63,742,977 } \\
\text { (July } 2014 \text { est.) }\end{array}$ & $\begin{array}{c}\text { 318,892,103 } \\
\text { (July } 2014 \text { est.) }\end{array}$ \\
\hline $\begin{array}{c}\text { Population Growth } \\
\text { Rate }\end{array}$ & $\begin{array}{c}1.09 \% \\
\text { (2014 est.) }\end{array}$ & $\begin{array}{c}0.54 \% \\
\text { (2014 est.) }\end{array}$ & $\begin{array}{c}0.77 \% \\
\text { (2014 est.) }\end{array}$ \\
\hline Life Expectancy & 82.07 years & 80.42 years & 79.56 years \\
\hline
\end{tabular}

Source: CIA World Fact Book (2015)

[NB: USA as a benchmark] 
Table 2: Dimensions of National Culture

\begin{tabular}{|c|c|c|c|c|}
\hline Country & IDV & PDI & UAI & MAS \\
\hline Australia & 90 & 36 & 51 & 61 \\
\hline United Kingdom & 89 & 35 & 35 & 66 \\
\hline USA & 91 & 40 & 46 & 62 \\
\hline
\end{tabular}

(Hofstede, 2017)

[NB: USA used as a benchmark]

Table 3: The Country of Business Domicile

\begin{tabular}{|l|c|c|c|c|}
\hline \multicolumn{1}{|c|}{ Country } & Aust & Aust & UK & UK \\
\hline & $\mathbf{n = 4 7}$ & $\mathbf{\%}$ & $\mathbf{n = 4 6}$ & $\mathbf{\%}$ \\
\hline & & & & \\
\hline Australia & $40^{*}$ & 85.1 & 0 & 0.0 \\
\hline UK & 3 & 6.4 & 25 & 54.3 \\
\hline USA & 1 & 2.1 & 9 & 19.6 \\
\hline European & 0 & 0.0 & 9 & 19.6 \\
\hline Ireland & $1^{* *}$ & 2.1 & 0 & 0.0 \\
\hline PNG & 1 & 2.1 & 0 & 0.0 \\
\hline Other & 1 & 2.1 & 3 & 6.5 \\
\hline Total & $\mathbf{4 7}$ & $\mathbf{1 0 0}$ & $\mathbf{4 6}$ & $\mathbf{1 0 0}$ \\
\hline
\end{tabular}

* an Australian company that identifies as UK based on the LSE

** an Australian company that identifies as Irish on the ASX 
Table 4: Conduct On Behalf of the Company

\begin{tabular}{|l|c|c|c|c|c|}
\hline & Aust & $\mathbf{A u s t}$ & $\mathbf{U K}$ & $\mathbf{U K}$ & $\mathbf{Z}$ test \\
\hline & $\mathbf{n = 4 7}$ & $\mathbf{\%}$ & $\mathbf{n = 4 6}$ & $\mathbf{\%}$ & \\
\hline 1. Relations with Home Gov't & 26 & 55.3 & 39 & 84.8 & 0.00 \\
\hline 2. Relations with customers & 44 & 93.6 & 44 & 95.7 & 0.66 \\
\hline 3. Relations with suppliers & 40 & 85.1 & 44 & 95.7 & 0.08 \\
\hline 4. Relations with employees & 42 & 89.4 & 42 & 91.3 & 0.75 \\
\hline 5. Employees health and safety & 39 & 83.0 & 44 & 95.7 & 0.05 \\
\hline 6. Relations with stakeholders & 32 & 68.1 & 32 & 69.6 & 0.90 \\
\hline 7. Relations with competitors & 19 & 40.4 & 38 & 82.6 & 0.00 \\
\hline 8. Relations with foreign gov'ts & 12 & 25.5 & 33 & 71.7 & 0.00 \\
\hline 9. Relations with investors & 32 & 68.1 & 37 & 80.4 & 0.17 \\
\hline \begin{tabular}{l} 
10. Civic and Community affairs \\
\hline 11. Relations with consumers
\end{tabular} & 31 & 66.0 & 39 & 84.8 & 0.04 \\
\hline 12. Environmental affairs & 10 & 21.3 & 19 & 41.3 & 0.04 \\
\hline 13. Product safety & 9 & 68.1 & 43 & 93.5 & 0.00 \\
\hline 14. Product quality & 17 & 36.2 & 26 & 56.5 & 0.00 \\
\hline $\begin{array}{l}\text { 15.Payments or political contributions } \\
\text { to gov'ts or gov't officials or } \\
\text { employees }\end{array}$ & 26 & 55.3 & 33 & 71.7 & 0.00 \\
\hline $\begin{array}{l}\text { 16. Acceptance of bribes, kickbacks, } \\
\text { gift/ entertainment }\end{array}$ & 42 & 89.4 & 42 & 91.3 & 0.10 \\
\hline $\begin{array}{l}\text { 17. Giving of bribes, kickbacks, } \\
\text { gifts/entertainment }\end{array}$ & 41 & 87.2 & 42 & 91.3 & 0.73 \\
\hline $\begin{array}{l}\text { 18. Other conduct on behalf of the } \\
\text { company }\end{array}$ & 32 & 68.1 & 39 & 84.8 & 0.06 \\
\hline
\end{tabular}


Table 5: Conduct Against the Company

\begin{tabular}{|l|c|c|c|c|c|}
\hline Conduct Against the Company & Aust & & $\mathbf{U K}$ & & Z test \\
\hline & $\mathbf{n = 4 7}$ & $\mathbf{\%}$ & $\mathbf{n = 4 6}$ & $\mathbf{\%}$ & \\
\hline 19. Conflict of interest & 47 & 100 & 44 & 95.1 & 0.15 \\
\hline $\begin{array}{l}\text { 20. Divulging trade secrets/proprietary } \\
\text { information }\end{array}$ & 45 & 95.7 & 42 & 91.3 & 0.38 \\
\hline 21. Insider trading information & 43 & 91.5 & 40 & 87.0 & 0.48 \\
\hline 22. Integrity of books and records & 30 & 63.8 & 42 & 91.3 & 0.00 \\
\hline $\begin{array}{l}\text { 23. Employee harassment and } \\
\text { discrimination }\end{array}$ & 39 & 83.0 & 44 & 95.7 & 0.05 \\
\hline 24. Relations with fellow employees. & 32 & 68.1 & 36 & 78.3 & 0.27 \\
\hline 25. Intellectual property rights & 16 & 34.0 & 35 & 76.1 & 0.00 \\
\hline 26. Use of corporate assets & 40 & 85.1 & 38 & 82.6 & 0.74 \\
\hline 27. Drugs including alcohol & 28 & 59.6 & 15 & 32.6 & 0.01 \\
\hline $\begin{array}{l}\text { 28. Communicating with the media } \\
\text { and outside publics }\end{array}$ & 27 & 57.4 & 26 & 56.5 & 0.93 \\
\hline 29. Post-employment obligations & 14 & 29.8 & 10 & 21.8 & 0.37 \\
\hline $\begin{array}{l}\text { 30. Participation in the political } \\
\text { process }\end{array}$ & 18 & 38.3 & 33 & 71.7 & 0.00 \\
\hline 31. Retaliation against others & 23 & 48.9 & 38 & 82.6 & 0.00 \\
\hline $\begin{array}{l}\text { 32. Use of computer software and or } \\
\text { hardware }\end{array}$ & 29 & 61.7 & 31 & 67.4 & 0.57 \\
\hline $\begin{array}{l}\text { 33. Truth in communication including } \\
\text { advertising }\end{array}$ & 15 & 31.9 & 29 & 63.0 & 0.00 \\
\hline 34. Personal character matters & 24 & 51.1 & 29 & 63.0 & 0.24 \\
\hline 35. Legal responsibility & 43 & 91.5 & 38 & 82.6 & 0.20 \\
\hline 36. Ethical responsibility & 42 & 89.4 & 40 & 87.0 & 0.71 \\
\hline $\begin{array}{l}\text { 37. Other conduct against the firm } \\
\text { 25 }\end{array}$ & 42 & 89.4 & 43 & 93.5 & 0.48 \\
\hline
\end{tabular}


Table 6: Laws and Conventions cited

\begin{tabular}{|l|c|c|c|c|c|}
\hline Laws and Conventions cited & Aust & Aust & UK & UK & Z test \\
\hline & $\mathbf{n = 4 7}$ & $\mathbf{\%}$ & $\mathbf{n = 4 6}$ & $\mathbf{\%}$ & \\
\hline 38. Competition Act/Anti-trust/TPA* & 26 & 55.3 & 40 & 87.0 & 0.00 \\
\hline 39. Securities & 28 & 59.6 & 25 & 54.3 & 0.61 \\
\hline 40. Environment & 4 & 8.5 & 26 & 56.5 & 0.00 \\
\hline 41. Food and Drugs & 0 & 0 & 7 & 15.2 & 0.00 \\
\hline 42. Product safety and quality & 4 & 8.5 & 11 & 23.9 & 0.04 \\
\hline 43. Worker health/safety & 15 & 31.9 & 21 & 45.7 & 0.17 \\
\hline $\begin{array}{l}\text { 44. Bribes or payments to gov'ts or } \\
\text { officials }\end{array}$ & 17 & 36.2 & 27 & 58.7 & 0.03 \\
\hline 45. False advertising & 1 & 2.1 & 4 & 8.7 & 0.16 \\
\hline 46. Copyright & 5 & 10.6 & 17 & 37.0 & 0.00 \\
\hline 47. Data protection & 23 & 48.9 & 28 & 60.9 & 0.25 \\
\hline 48. EEO and discrimination & 25 & 53.2 & 21 & 45.7 & 0.47 \\
\hline 49. Boycott & 7 & 14.9 & 25 & 54.3 & 0.00 \\
\hline 50. Money laundering & 7 & 14.9 & 17 & 37.0 & 0.02 \\
\hline 51. Labour & 7 & 14.9 & 28 & 60.9 & 0.00 \\
\hline 52. Human Rights & 10 & 21.3 & 29 & 63.0 & 0.00 \\
\hline 53. UN Global Compact & 6 & 12.8 & 9 & 19.6 & 0.37 \\
\hline 54. Other laws/conventions & 25 & 43.2 & 41 & 89.1 & 0.00 \\
\hline
\end{tabular}

Table 7: Government Agencies and Conventions

\begin{tabular}{|l|c|c|c|c|c|}
\hline $\begin{array}{l}\text { Government Agencies and } \\
\text { Conventions }\end{array}$ & Aust & Aust & UK & UK & Z test \\
\hline & $\mathbf{n = 4 7}$ & $\mathbf{\%}$ & $\mathbf{n = 4 6}$ & $\mathbf{\%}$ & \\
\hline 55. Competition Tribunal / TPA & 1 & 2.1 & 3 & 6.5 & 0.30 \\
\hline 56. UN & 6 & 12.8 & 17 & 37.0 & 0.01 \\
\hline 57. OECD & 3 & 6.4 & 6 & 13.0 & 0.28 \\
\hline 58. ILO & 2 & 4.3 & 11 & 23.9 & 0.01 \\
\hline 59. Other agencies/conventions & 1 & 2.1 & 3 & 6.5 & 0.30 \\
\hline
\end{tabular}


Table 8: Types of Compliance/Enforcement

\begin{tabular}{|l|c|c|c|c|c|}
\hline Types of Compliance/Enforcement & Aust & Aust & UK & UK & Z test \\
\hline \multicolumn{1}{|c|}{ Internal Oversight } & $\mathbf{n = 4 7}$ & $\mathbf{\%}$ & $\mathbf{n = 4 6}$ & $\mathbf{\%}$ & \\
\hline \multicolumn{1}{|c|}{} & & & & & \\
\hline 60. Supervisor surveillance & 2 & 4.3 & 6 & 13.0 & 0.13 \\
\hline 61. Internal watchdog committee & 5 & 10.6 & 4 & 8.7 & 0.75 \\
\hline 62. Internal audits & 7 & 14.9 & 9 & 19.6 & 0.55 \\
\hline 63. Read and understand affidavit & 0 & 0 & 0 & 0 & - \\
\hline $\begin{array}{l}\text { 64. Routine financial budgetary } \\
\text { review }\end{array}$ & 0 & 0 & 0 & 0 & - \\
\hline 65. Legal department review & 6 & 12.8 & 15 & 32.6 & 0.02 \\
\hline 66. Other oversight procedures & & & & & \\
\hline \multicolumn{1}{|c|}{ Internal-Personal Integrity } & 42 & 89.4 & 36 & 65.2 & 0.14 \\
\hline 67. Supervisor & 4 & 8.5 & 7 & 15.2 & 0.32 \\
\hline 68. Internal watchdog committee & 22 & 46.8 & 26 & 56.5 & 0.35 \\
\hline 69. Corporation's legal counsel & 2 & 4.3 & 3 & 6.5 & 0.63 \\
\hline 70. Compliance affidavits & 43 & 91.5 & 41 & 89.1 & 0.70 \\
\hline 71. Employee integrity & 17 & 36.2 & 16 & 34.8 & 0.89 \\
\hline 72. HRM department & 12 & 25.5 & 21 & 45.7 & 0.04 \\
\hline 73. Senior management role models & 27 & 57.5 & 31 & 67.4 & 0.32 \\
\hline 74. Other (in firm) & & & & & \\
\hline \multicolumn{1}{|c|}{ External } & 0 & 0 & 0 & 0 & - \\
\hline 75. Independent auditors & 0 & 0 & 0 & 0 & - \\
\hline 76. Law enforcement & 6 & 12.8 & 15 & 32.6 & 0.02 \\
\hline 77. Other external & & & &
\end{tabular}

Table 9: Penalties for Illegal Behaviour

\begin{tabular}{|c|c|c|c|c|c|}
\hline Penalties for Illegal Behaviour & Aust & Aust & UK & UK & $\mathrm{Z}$ test \\
\hline & $\mathrm{n}=47$ & $\%$ & $n=46$ & $\%$ & \\
\hline \multicolumn{6}{|l|}{ Internal } \\
\hline 78. Reprimand & 9 & 19.1 & 4 & 8.7 & 0.15 \\
\hline 79. Fine & 2 & 4.3 & 4 & 8.7 & 0.39 \\
\hline 80. Demotion & 4 & 8.5 & 1 & 2.2 & 0.18 \\
\hline 81. Dismissal/Firing & 40 & 85.1 & 25 & 54.3 & 0.00 \\
\hline 82. Other internal penalty & 29 & 61.7 & 35 & 76.1 & 0.13 \\
\hline \multicolumn{6}{|l|}{ External } \\
\hline 83. Legal prosecution & 25 & 53.3 & 26 & 56.5 & 0.75 \\
\hline 84. Other external penalty & 4 & 8.5 & 5 & 10.9 & 0.70 \\
\hline
\end{tabular}


Table 10: General Information

\begin{tabular}{|l|c|c|c|c|c|}
\hline General Information & Aust & Aust & UK & UK & Z test \\
\hline & $\mathbf{n = 4 7}$ & $\mathbf{\%}$ & $\mathbf{n = 4 6}$ & $\mathbf{\%}$ & \\
\hline $\begin{array}{l}\text { 85. Need to maintain corporation's } \\
\text { good reputation }\end{array}$ & 33 & 70.2 & 39 & 84.8 & 0.09 \\
\hline $\begin{array}{l}\text { 86. Letter/Introductory remarks from } \\
\text { the President/CEO/Chairperson of the } \\
\text { Board }\end{array}$ & 26 & 55.3 & 41 & 89.1 & 0.00 \\
\hline
\end{tabular}




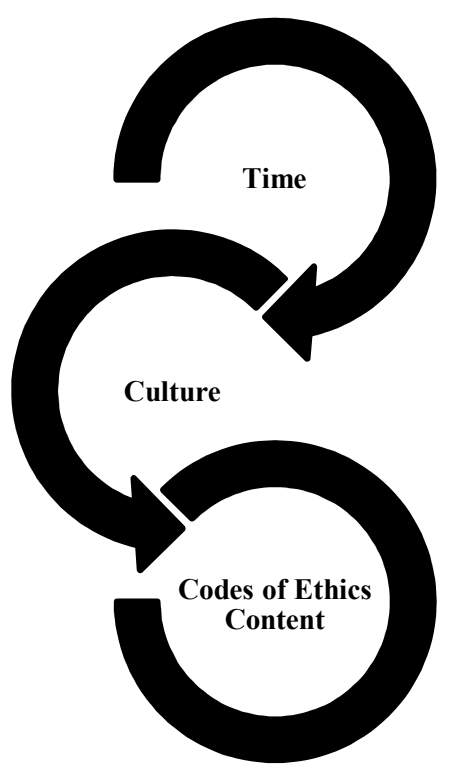

Figure 1: Code of Ethics Content through Time and across Cultures

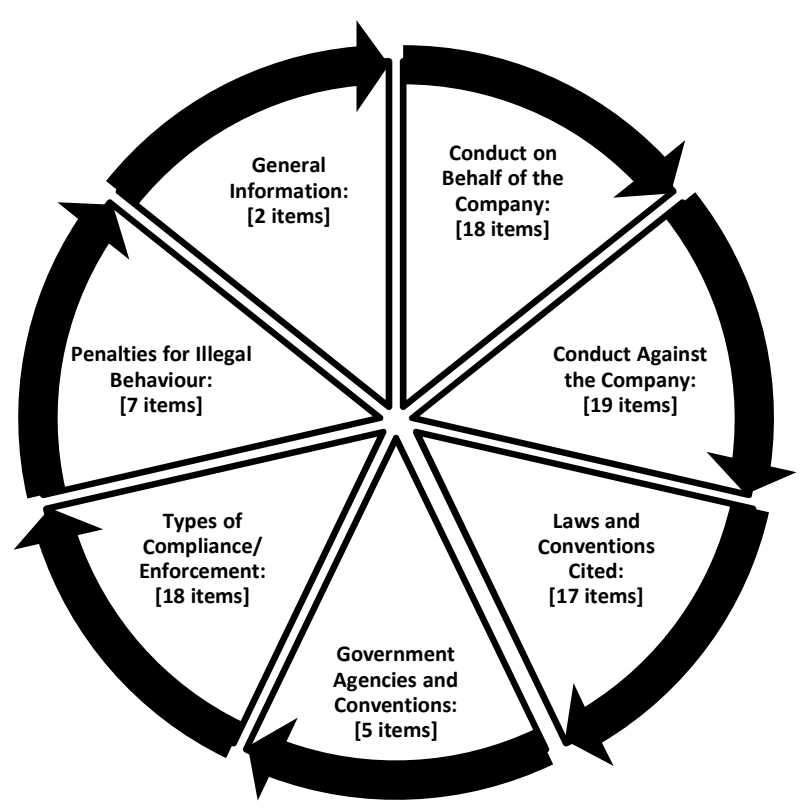

Figure 2: Content of Codes of Ethics - Dimensions

[NB: The direction of the arrows signifies the step by step progression of the analysis of the code documents commencing at 'Conduct on Behalf of the Company'] 